\title{
QUALITY OF LIFE IN SELECTED PSYCHOLOGICAL CONCEPTS
}

\begin{abstract}
This article presents a short history of the term, "quality of life", its origins and related terms/concepts as well as its use in disciplines other than psychology. The article presents several general models and concepts of the quality of life in psychology, and among many different theories and specific concepts of the quality of life, it describes in detail the less known Straś- Romanowska's psychological personalistic and existential concept of the quality of life, which concentrates on four dimensions: psychophysical (biological), psychosocial, subjective, and metaphysical (spiritual). This concept of the quality of life derives from person-oriented psychology and philosophical anthropology. It presents a holistic and subjective view of the quality of life of a human, and it concentrates on the experiences, relationships, actions and development of a person.
\end{abstract}

Keywords: quality of life, psychological concepts, well-being.

\section{INTRODUCTION}

The concept of quality of life appeared in social sciences after World War II. In the 1950s, quality of life concepts were increasingly used in economics, social policy, medicine, sociology and psychology (Trzebiatowski, 2011). In the second half of the twentieth century it was noted that not only life expectancy was important, but above all its quality (Roop et al., 2011). In psychology, one of the first studies on the quality of life was the work of Campbell, Convers and Rogers (1976). They evaluated changes taking place in the psychological dimension of human life. The basic indicator of the quality of life in these studies was perceived satisfaction in such areas as family, marriage, residence, apartment, neighborhood, friends and acquaintances, health, housework, work, education level, usefulness of education, leisure time, standard of living and possessed savings. According to Campbell, quality of life is a result of personal properties as well as objective and subjective indicators of well-being. The factors highlighted by Campbell that determine a high or low quality of life can be considered in the category of needs (Campbell, 1981).

Nowadays, however, there is no uniform definition of the quality of life, and various authors distinguish other aspects and areas of this variable and use various tools to measure this phenomenon (Roop et al., 2011). There are also various concepts related and close in meaning, sometimes used interchangeably with the concept of quality of life, such as happiness, well-being, life satisfaction (Armstrong and Caldwell, 2004).

\footnotetext{
1 Agata Wolanin, PhD, Rzeszow University of Technology, The Faculty of Management, Department of Humanities and Social Sciences, 12 Powstańców Warszawy Ave., 35-959 Rzeszów; e-mail: a.wolanin@prz.edu.pl. ORCID: 0000-0001-7679-9232.
} 
Quality of life is often equated with well-being, defined as cognitive and emotional assessment of one's own life, including experiencing pleasant emotions, low levels of negative emotions, and high levels of life satisfaction (Diener, Lucas, Oishi, 2002). The most commonly used theories come from the philosophical approach to good life: hedonism and eudaimonism. Subjective well-being consists of high positive affect, low negative affect and high life satisfaction, which is a conceptualisation of emotional functioning (Joseph and Wood, 2010). In this approach, well-being means a satisfying and emotionally pleasant life, in simple terms - a happy life. Eudaimonistic well-being, also called psychological well-being, refers to a full and valuable life, accompanied by the use of its potential and personal growth (Ryan and Deci, 2001). Subjective well-being and psychological well-being are two separate constructs derived from different theoretical concepts. They are also two separate factors (Linley, Maltby, Wood, Osborne and Hurling, 2009).

\section{QUALITY OF LIFE - TERMINOLOGICAL ISSUES}

The concept of quality of life is currently used in many contexts, including politics, education, advertising, social sciences and healthcare (Roop, Payne and Vallerand, 2011). In the economic dimension, quality of life is identified with consumption and material status (Bańka, 1994). Studies on the relationship between material level and happiness and well-being have shown that the relationship between wealth and happiness is weak $(r=0.20$; Diener, Sandvik, Seidlitz, Diener, 1993). It has been proved (Diener, Horwitz and Emmons, 1985) that wealthy people are not much happier than others. Studies on the relationship between the wealth of citizens of different countries and their level of well-being have shown that people in rich countries are happier only until they achieve a certain level of wealth, and after exceeding it, the relationship between wealth and happiness weakens. However, in poor countries this relationship is stronger. Citizens living in the richest countries were not happier than those in countries with average per capita incomes (Myers, 2000). In examining the relationship between the wealth of a given country and the well-being of citizens over the years, it turned out that the increase in wealth of a given population does not have to be accompanied by greater declared happiness, and often it is the opposite. In the United States, coexistence of increasing material well-being with decreasing social well-being has been observed (Myers, 2000). The importance of the material aspect of quality of life, intuitively recognized as crucial by many people, has been diminished due to research on correlates of human happiness and well-being.

In the 1960s, quality of life assessment was mainly based on objective indicators such as income, place of residence, employment and education (Morrison and Morrison, 2006). The importance of subjective perception of quality of life has been highlighted in the concept of the World Health Organization (WHOQOL Group, 1994). At present, subjective quality of life is assessed more often and self-description methods are used. As de Walden-Gałuszko (1997) notes, the quality of life, initially expressed in the state of ownership (the "have" area) has been extended to "be" areas, such as freedom, health and happiness. This led to the definition of a general assessment of the quality of life as a picture of one's life position, carried out in a selected period of time, i.e. the assessment of a fragment of life in the relationship between man and his external and internal environment. Life position is an objective situation, independent of human views and emotions, e.g. the degree of reduced mobility. Assessment of the situation is conditioned by the experiences of the assessor and therefore is largely subjective, especially when it is a direct assessment of one's own 
situation. Although the assessment of life position can be made more objectively by outsiders, such as a psychologist or doctor, this is rather additional information, and the assessment of one's own quality of life is considered the most important and correctly obtained source of information (de Walden-Gałuszko, 1997). To emphasize the subjectivity of the quality of life and its distinction from economic and medical objective indicators, the concept of subjective quality of life, perceived quality of life, subjective well-being and psychological well-being is used (Oleś, 2010).

There are many definitions of quality of life, however, as King (2011) notes, most researchers agree that this is a multidimensional, subjective and dynamic construct consisting of both positive and negative aspects of life (e.g. Grant, Padilla, Ferrel and Rhiner, 1990; Mellon, 2002). The multidimensionality of quality of life is expressed in areas such as physical, psychological, social, somatic and spiritual (Schipper, 1991). The physical dimension usually includes strength, energy, the ability to cope with daily activities and self-service. The psychological dimension often includes symptoms such as anxiety, depression and fear. The social area refers to relationships with family, friends, work colleagues and the community. The somatic aspect of quality of life means symptoms of the disease and side effects of treatment, e.g. pain. The spiritual dimension refers to the perception of purpose in life and meaning (King, 2011). The measurement of quality of life is most often done using self-description tools. Quality of life is usually measured on a continuum, as an individual perception that can change over time.

\section{GENERAL MODELS OF QUALITY OF LIFE}

Several general quality of life models have been described in the literature. BortwickDuffy (1992; after: Oleś, 2010) distinguishes three types of quality of life models: 1) quality of life as the quality of life of an individual, 2) as satisfaction with living conditions, and 3 ) as the sum of living conditions and satisfaction unit. Quality of life understood as the quality of living conditions is the sum of assessments of objective living conditions, such as physical health, resources, wealth, housing, occupation, social relations as well as social and economic determinants of socioeconomic status. The quality of life in this approach is determined by assessing the living conditions compared to the general population, and subjective assessments of life satisfaction are not taken into account. In the second approach, quality of life is synonymous with contentment in life in its various areas, such as material status, health, work, education, development, social relations, marriage and others. So understood life satisfaction is influenced by both objective living conditions and subjective factors, e.g. health assessment. In the quality of life understood as the sum of living conditions and individual satisfaction, an objective assessment of various areas of life is taken into account, expressed by biological, material, social and psychological indicators as well as a subjective assessment of each of these areas. This subjective feeling towards particular areas of life takes the form of satisfaction or well-being.

Definitions of quality of life include definitions emphasizing achievement of personal goals, sense of contentment / happiness, social utility (Burckhardt, 2000), as well as definitions expressing quality of life in a holistic way (Felce and Perry, 1995). Felce and Perry in their holistic quality of life model include: physical well-being, material well-being, social well-being, emotional well-being and well-being in the sphere of productivity. The authors of this approach therefore define the quality of life as general well-being, listing sixteen specific areas: mental health, physical health, sexual sphere, social skills, exercising, employment, education, leisure, recreation, sport, friendship, 
nutrition, home life, initiative and social life, marriage and participation, family. Quality of life can be assessed at several levels: personal values, life satisfaction and objective living conditions (Perry and Felce, 2002). This concept therefore combines objective and subjective indicators of quality of life.

A similar approach to the quality of life, which takes into account objective and subjective aspects, is presented by Sęk (1993). The quality of life in this approach is defined as the result of valuing various spheres of life and life understood as a whole. The subjective quality of life is a subjective and cognitive-emotional category, which is expressed by means of life satisfaction and can take the form of a temporary sense or a generalized attitude towards life (Adamczyk and Sęk, 1997). Typology of quality of life includes both objective living conditions (favorable or unfavorable) and subjective assessment of the quality of one's own life, positive or negative. These two dimensions divide the perceived quality of life into four categories. Objectively favorable living conditions co-occurring with a positive assessment constitute "justified satisfaction". The occurring negative assessment of life under objectively favorable conditions sets the "dilemma of dissatisfaction". A positive assessment of life in objectively unfavorable conditions gives a "satisfaction paradox". Negative assessment of life coexisting with adverse conditions means "justified dissatisfaction". One can also distinguish three common health concepts formulated by patients (Sęk, 1993).

The first is the biomedical definition, according to which health is only the absence of symptoms of the disease. The second of the colloquial definitions includes health as a set of objective features constituting human resources, such as resilience or constitutionally conditioned potentials. The third definition equates health with a sense of biological, psychological and social well-being.

\section{THE WORLD HEALTH ORGANIZATION (WHO) QUALITY OF LIFE MODEL}

The WHO constitution defines health as "a state of complete physical, mental and social well-being, not just a lack of illness ...". From this definition, it follows that measuring health and health effects must include not only an indication of changes in the frequency and severity of the disease, but also an assessment of well-being. This can be done by assessing the improvement of quality of life related to healthcare.

The concept and model of quality of life developed by the WHOQOL Group (1994) refer to this definition of health. The concept of quality of life is defined by WHO as "the individual's perception of his position in life in the context of the culture and value systems in which he lives, and in relation to his goals, expectations, standards and fears", emphasizing the subjectivity of this phenomenon (WHOQOL Group, 1995). The WHO quality of life covers six general areas and 24 specific aspects of quality of life. The overall dimensions of the quality of life in this model include physical health, mental state, level of independence, social relationships, environmental features and spiritual area. Therefore, the quality of life is considered a broad concept, which is influenced in a complex way by a person's physical health, mental state, level of independence, area of social relations, personal beliefs and their relationship with the environment.

The physical sphere in this model includes such components as sensory sensations, energy and fatigue, pain and discomfort as well as sleep and rest. The psychological domain 
contains subcategories such as body image and appearance, negative feelings, positive feelings, self-esteem and mental processes (thinking, learning, memory and concentration). The dimension of independence includes motor independence, daily activities, ability to communicate, dependence on medical substances and medical assistance and the ability to work. The area of social relations is personal relationships, experienced social support and supporting other people. The environmental dimension includes elements such as financial resources, freedom and physical security, job satisfaction, health and social care, home environment, access to new information, leisure and leisure time, physical environment (pollution, noise, traffic, climate) and transport. The spirituality / religion / personal beliefs dimension includes religious beliefs and practices (WHOQOL Group, 1998). The quality of life in this concept is a multidimensional construct referring to the physical and mental health of a person and his relationship with the physical and social environment, including his level of independence as well as views and beliefs. The quality of life in this approach is subject to subjective assessment, embedded in a broad cultural, environmental and social context, including many factors. Therefore, the concept of quality of life is not synonymous with terms such as health, lifestyle, mental state, life satisfaction or well-being, although these may be elements of quality of life (Oleś, 2010). According to WHO (1997), measuring quality of life can improve patient-physician interactions by better understanding how disease affects the patient's quality of life. WHO, in cooperation with fifteen centers around the world, has developed two tools for measuring the quality of life (WHOQOL-100 and WHOQOL - BREF), which can be used to study people living in different cultures, while allowing comparison of the results of people from different societies and countries.

According to WHO, these tools have many uses, including in medical practice and scientific research. Important aspects of the quality of life are highlighted on the basis of statements made by people suffering from various diseases and health professionals living in different cultures. The WHOQOL quality of life measurement tool is currently available in more than twenty languages (WHO, 1997). The concept and definition of the WHO quality of life is most often used in psychological research of this variable.

\section{PERSONALISTIC AND EXISTENTIAL CONCEPT OF M. STRAŚ-ROMANOWSKA'S QUALITY OF LIFE}

In psychology, in addition to external categories of quality of life, subjective factors such as the value system, individual life goals, aspirations and life history have also been taken into account. This resulted in the concept of "sense of quality of life", which includes the experience and experience component of human regulatory processes (Derbis, 2000). The sense of quality of life has an individual, individual dimension and involves more mental processes compared to the quality of life (Derbis, 2000; Kowalik, 1993; Straś-Romanowska, 2005 [see: Mróz, 2011]).

The personalistic existential model of quality of life comes from the current of person-oriented psychology and philosophical anthropology (Straś-Romanowska, 2005). In person-oriented psychology, the subject of research is man as an individual, complex and irreducible whole, and elements of mental life are recognized against the background of this whole. In addition, the basic human attributes are included in this trend: reflective awareness, intentionality and moral sensitivity. From the methodological point of view, person-oriented psychology includes, in addition to nomotetic research, also idiographic research and respects views and research results from various fields of knowledge about 
man, favoring eclecticism and holistic views regarding complex phenomena. Philosophical anthropology, mainly personalism, existentialism and the philosophy of dialogue provide assumptions about human life. It allows to define human life as existence and being -in-the-world, that is, conscious and reflective existence (Baran, 1991). His main forms are experiencing the world and yourself in the world, being in dialogue with others, intentional action and creative personal development (becoming). These are specific forms of the sense of quality of life.

Experiencing the world and yourself in the world is a complex, holistic and irreducible cognitive process that involves all mental (emotional, intellectual, image and symbolic) functions, not just emotional and sensual experience (Straś-Romanowska, 1992). An important element of experience that plays a significant role in making subjective assessments (including assessing one's own life) is reflective thinking, which is based on postformal mental structures and becomes active with age. The effect of these experiences are meanings that set subjective criteria for evaluating events and making important choices, as well as shaping the concept of the world and oneself in the world (Straś-Romanowska, 2005). The most important experiences related to oneself and to higher values (like truth, goodness and beauty) create an individual psychic atmosphere that accompanies and dynamizes human activity.

Being in dialogue with others is related to the dialogical nature of human nature. Dialogue is a direct relationship with other people, the world of nature and culture, transcendental beings and also with ourselves. It is a direct bond based on full and authentic openness to another, characterized by unconditional acceptance, and its opposite is existential loneliness. Staying in a dialogue with others is a primary human experience and a way of existence. Above all, however, it is a condition of harmony and harmony with the world and a sense of community, as well as realistic self-knowledge and full self-acceptance.

Intentional actions are conscious and goal-oriented behaviors that adapt to changing environmental conditions and provide a source of satisfaction, a sense of control and self-esteem. In addition to the goal of activity, intention is also important, meaning sense of behavior and justifying value, which means that the subject is aware not only of what he is pursuing, but also why he is pursuing a given goal. It provides sense in its own actions.

Becoming, or creative personal development, runs differently at different stages of life. In childhood and youth, development is geared towards social adaptation and takes place through the processes of maturation and learning. In adulthood, however, the role of interpretation and reinterpretation of accumulated experiences dominates in development. The goal of development is internal and subjective adaptation, which involves the integration of mental life structures, and spiritual and existential adaptation, which consists in identifying and verifying the compliance of one's actions with the message received through absolute values and transcendental phenomena. The most important manifestations of subjective and existential adaptation include the harmony of thoughts, feelings and actions, commitment to actions that give a sense of fulfillment as well as joy of life and a sense of meaning even despite difficulties encountered (Straś-Romanowska, 2005).

Subjective existence, called existence, is the distinguishing feature of a person. Existence (or being-in-the-world) means experiencing and experiencing one's own existence in relation to other beings and intentionally referring to reality, to other people, to oneself and to values (Luijpen 1972; Krasnodębski, 1986; after: Straś-Romanowska, 1995). A special form of intentional, conscious way of existence is self-awareness, i.e. 
experiencing the events of one's own life, a way of responding to them, reflection on oneself and the sense and purpose of one's existence (Straś-Romanowska, 1995).

The quality of life in this concept means a way of life and accompanying feelings. It includes the type of individual experience, relationships with people, the surrounding world and with oneself as well as the type and effects of implemented activities, personal development and emotional mood occurring in the implementation of a given way of life (Straś-Romanowska, 2005). The quality of life is assessed by the assessor, and therefore it is a subjectively assessed quality of life. The quality of life assessment is the answer to the question "how a person lives" and "to what extent he is happy with his way of life" (Straś-Romanowska, 2005). In this concept, conscious, reflective experiencing, being in a dialogue with others, intentional actions and creative development take place on various dimensions (such as experiences, relationships, actions and development). Four such dimensions have been distinguished: biological (psychophysical), social (psychosocial), subjective and spiritual (The psychophysical area includes human biology, drives, physical appearance, temperament and vitality. The biological dimension in the form of experiencing the world and oneself in the world includes physical well-being. The dialogue of this dimension is manifested in the understanding and acceptance of one's body. Intentionality includes health-promoting behaviors, and creative development takes the form of optimal aging. The quality of life in this dimension of mental life means biological adaptation. It is governed by the principle of homeostasis, which covers the biological needs of the body. The affective components of this mental life are physical pleasure and pain.

The psychosocial sphere is social relations, expectations of the environment, level of adaptation, establishing and maintaining emotional bonds, acceptance and self-esteem. Experiencing the world and yourself in the world in dimension psychosocial takes the form of a sense of security and social power. Dialogue in this dimension includes understanding with others and a sense of community. Intentionality manifests itself in social behavior, such as performing roles and completing tasks. Becoming in this dimension means transgression through the increase of competence and social power. The quality of life in this dimension of mental life takes the form of social adaptation. It depends on meeting the principle of heteronomy, i.e. living in harmony with the environment and meeting social requirements. Satisfaction (pride, pragmatic sense) and dissatisfaction (annoyance, disappointment, failure) are the affective components of this dimension's mental life.

The subjective aspect of quality of life means emphasizing your individuality, independence, isolation from the social background, taking responsibility for your own choices and decisions, the possibility of self-realization, being authentic and developing your own interests. The subjective dimension in the form of experiencing includes a sense of freedom and authenticity, i.e. being yourself. Dialogue in this dimension is manifested in self-understanding and self-acceptance as well as harmony with oneself. Intentionality includes behaviors that respect self-interest. Becoming happens through self-updating. The quality of life in this dimension of mental life means subjective adaptation. It is governed by the principle of autonomy, and the affective components of mental life in this dimension are the joy of existence (e.g. flow experience) and the burden of existence.

The metaphysical sphere includes spirituality, the realization of universal and timeless values, such as good, truth, beauty and religious experiences, also giving meaning to life, also in the context of transience. The development of this sphere is conducive to shaping moral responsibility and declarations of conduct in accordance with one's conscience. The experience of the world and oneself in the world in the metaphysical dimension occurs in 
the form of metaphysical experiences (e.g. truth, good, beauty) and border experiences (suffering, death). The dialogue of this dimension includes metaphysical identity, i.e., consent to fate and "agreement" with transcendent beings. Action manifests itself in behaviors that realize absolute values. Becoming in this dimension means self-transcendence. The quality of life in this dimension of mental life takes the form of spiritual / existential adaptation, depending on the principle of homonomy, i.e. living in harmony with moral principles and spiritual development, leading to a sense of meaning in life, an affective component of the mental life of this dimension. His opposite is spiritual suffering, i.e. existential emptiness and despair (Straś-Romanowska, 2005).

In the above concept, quality of life is a complex and multidimensional phenomenon. The spheres of existence (psychophysical, psychosocial, subjective and metaphysical) exert an influence on the internal integrity of man in the development process, they are also relatively independent from each other (Straś-Romanowska and Frąckowiak, 2007). The model of personal spheres is a harmonious arrangement. The metaphysical sphere is a factor that organizes a personal whole.

In the Straś-Romanowska concept (2005), the psychophysical and psychosocial sphere belong to the naturalistic dimension, i.e. the social world. The subjective and metaphysical sphere belong to the spiritual dimension, which is defined by searching for the meaning of existence. Psychosocial, subjective and metaphysical spheres belong to the area of culture in which behavior patterns, values, and ways of feeling and reacting in typical situations are located. This concept can be incorporated into eudaimonistic concepts by referring to one's own experiences and attributing great importance to realizing values.

\section{CONCLUSIONS}

The concept of 'quality of life' can be analyzed from different angles. There are a number of definitions, models and concepts for quality of life. It is also possible to indicate synonyms of this term, such as well-being or happiness. Quality of life can also be considered in terms of individual aspects, such as physical or social. Often, researchers also introduce modifications to known quality of life models and adapt them to the needs of their own research, or construct models for specific groups, e.g. due to age and specific quality of life criteria.

One of the taxonomies of the definition of quality of life (Farquhar, 1995) divides them into two groups: professional (developed by quality of life researchers) and colloquial. Among the professional definitions there are global, complex, specific and mixed definitions. Global definitions include an assessment of the whole of life and an assessment of overall life satisfaction and well-being in various spheres of life as well as a sense of happiness. In addition to global assessment, complex definitions also include various partial areas of life, and their assessment has an impact on global quality of life. Specific definitions focus on specific areas of life. Mixed definitions, also called superior ones, include elements of global and complex definitions and additionally include dimensions such as the external environment, individual expectations or economic conditions in their scope.

\section{REFERENCES}

Adamczyk, M., Sęk, H. (1997). Znaczenie pojęcia ,jakość życia” w opiece psychologicznej pacjentów onkologicznych [w:] Meyza, J., red., Jakość życia w chorobie nowotworowej (s. 248-260). Warszawa: Centrum Onkologii Instytutu im. Marii Skłodowskiej-Curie. 
Armstrong, D., Caldwell, D. (2004). Origins of the concept of quality of life in health care: A rhetorical solution to a political problem. "Social Theory and Health", 2(4).

Bańka A. (1994). Jakość życia w psychologicznych koncepcjach człowieka i pracy [w:] Bańka, A., Derbis, R., red., Psychologiczne i pedagogiczne wymiary jakości życia (s. 19-40). Poznań: Wydawnictwo UAM.

Baran, B. (1991). Filozofia dialogu. Kraków: Wydawnictwo Znak.

Burckhart, C. S. (2000). Quality of life compendium: Conceptualizing quality of life. Center for Quality of Life Research in Nursing Science. University of Bergen.

Campbell, A. (1981). The sense of well-being in America: Recent patterns and trends. Institute for Social Research.

Campbell, A., Converse, P. E., Rodgers, W. L. (1976). The quality of American life: Perceptions, evaluations, and satisfactions. Russell Sage Foundation.

De Walden-Gałuszko, K. (1997). Ocena jakości życia uwarunkowana stanem zdrowia [w:]: Meyza, J., red., Jakość życia w chorobie nowotworowej (s. 77-84). Warszawa: Centrum Onkologii Instytutu im. Marii Skłodowskiej-Curie.

Derbis, R., red., (2000). Jakość rozwoju a jakość życia. Częstochowa: Wydawnictwa WSP.

Diener, E., Horwitz, J., Emmons, R. A. (1985). Happiness of the very wealthy. "Social Indicators Research", 16(3).

Diener, E., Lucas, R. E., Oishi, S. (2004). Dobrostan psychiczny. Nauka o szczęściu i zadowoleniu z życia [w:] Czapiński, J., red., Psychologia pozytywna. Nauka o szczęściu, zdrowiu, sile i cnotach czlowieka (s. 35-50). Warszawa: Wydawnictwo Naukowe PWN.

Diener, E., Sandvik, E., Seidlitz, L., Diener, M. (1993). The relationship between income and subjective well-being: Relative or absolute? "Social Indicators Research", 28(3).

Farquhar, M. (1995). Definitions of quality of life: a taxonomy. "Journal of Advanced Nursing”, 22(3).

Felce, D., Perry, J. (1995). Assessment of Quality of Life: Its Definition and Measurement. "Research in Developmental Disabilities", 16.

Grant, M. M., Padilla, G. V., Ferrel, B. R., Rhiner, M. (1990). Assessment of quality of life with a single instrument. "Seminars of Oncology Nursing", 6.

Joseph, S., Wood, A. M. (2010). Assessment of positive functioning in clinical psychology: Theoretical and practical issues. "Clinical Psychology Review", 30.

King, C. R. (2011). Overview of Quality of Life and Controversial Issues [w:] King, C. R., Hinds, P. S., red., Quality of Life: From Nursing and Patient Perspectives: Theory, Research, Practice (s. 31-41). Jones and Bartlett Publishers.

Kowalik, S. (1993). Psychologiczne wymiary jakości życia [w:] Bańka, A., Derbis, R., red., Myśl psychologiczna w Polsce odrodzonej. Efektywność działań człowieka (s. 58-72). Poznań: Genius.

Linley, P. A., Maltby, J., Wood, A. M., Osborne, G., Hurling, R. (2009). Measuring happiness: The higher order factor structure of subjective and psychological well-being measures. "Personality and Individual Differences", 47.

Morrison, L. J., Morrison, S. (2006). Palliative care and pain management. "The Medical Clinics of North America", 90.

Mróz, B. (2011). Poczucie jakości życia u pracowników wyższego szczebla. Uwarunkowania osobowościowe i aksjologiczne. Warszawa: Wydawnictwo Naukowe Scholar.

Myers, D. G. (2000). The funds, friends, and faith of happy people. "American Psychologist", $55(1)$. 
Oleś, M. (2010). Jakość życia w zdrowiu i w chorobie. Lublin: Wydawnictwo KUL.

Roop, J. C., Payne, J. K.,Vallerand, A. H. (2011). Theories and Conceptual Models to Guide Quality-of-Life Research [w:] King, C. R., Hinds, P. S., red., Quality of Life: From Nursing and Patient Perspectives: Theory, Research, Practice (s. 45-57). Jones and Bartlett Publishers.

Ryan, R. M., Deci, E. L. (2001). On happiness and human potentials: A review of research on hedonic and eudemonic well-being. "Annual Review of Psychology", 52.

Schipper, H. (1991). Guidelines and caveats for quality of life measurement in clinical practice and research [w:]: Tchekmedyian, N. S., Cella, D. F., red., Quality of life in oncology practice and research (s. 25-31). Willoston Park, NY: Dominus Publishing Company.

Sęk, H., (1993). Jakość życia a wymiary zdrowia. „Ruch Prawniczy, Ekonomiczny i Socjologiczny”, 2.

Straś-Romanowska, M. (1995). Główne idee teoretyczne i metodologiczne psychologii personalistyczno-egzystencjalnej jako dyscypliny humanistycznej [w:] Straś-Romanowska, M., red., Na tropach psychologii jako nauki humanistycznej. Warszawa-Wrocław: Wydawnictwo Naukowe PWN.

(1992). Los czlowieka jako problem psychologiczny. Podstawy teoretyczne. Wrocław: Wydawnictwo Uniwersytetu Wrocławskiego.

(2005). Jakość życia w świetle założeń psychologii zorientowanej na osobę [w:] StraśRomanowska, M., Lachowicz-Tabaczek, K., Szmajke, A., red., Jakość życia w badaniach empirycznych i refleksji teoretycznej (s. 263-274), Kolokwia Psychologiczne, 13. Warszawa: Instytut Psychologii PAN.

Straś-Romanowska, M., Frąckowiak, T. (2007). Rola relacji międzyludzkich $w$ budowaniu jakości życia osób niepetnosprawnych (perspektywa personalistyczno-egzystencjalna [w:] Patkiewicz, J., red., Rola więzi w rozwoju dzieci i młodzieży niepetnosprawnej (s. 47-57). Wrocław: TWK-Wrocław.

Trzebiatowski, J. (2011). Jakość życia $w$ perspektywie nauk społecznych $i$ medycznych systematyzacja ujęć definicyjnych. „Hygeia Public Health”, 46(1).

WHOQOL Group (1995). WHOQOL Group, The World Health Organization Quality of Life Assessment: Position Paper from the World Health Organization. "Social Science and Medicine”, 41.

— (1998). WHOQOL Group, The World Health Organization Quality of Life Assessment (WHOQOL): Development and general psychometric properties. "Social Science and Medicine", 46.

— (1994). WHOQOL Group, The Development of the World Health Organization Quality of Life Assessment Instrument [w:] Orley, J., Kuyken, W., red., Quality of life assessment: International perspectives (s. 41-57). Berlin: Springer.

World Health Organization (1997). WHOQOL - Measuring Quality Of Life. The World Health Organization Quality of Life Instruments. WHO/MSA/MNH/PSF/97.4.

DOI: $10.7862 /$ rz.2021.hss.38

The text was submitted to the editorial office: September 2021.

The text was accepted for publication: December 2021. 